IZA DP No. 7367

Foreign Scientists and Engineers and Economic Growth in Canadian Labor Markets

Giovanni Peri

Kevin Y. Shih

April 2013

Forschungsinstitut zur Zukunft der Arbeit Institute for the Study of Labor 


\title{
Foreign Scientists and Engineers and Economic Growth in Canadian Labor Markets
}

\author{
Giovanni Peri \\ UC Davis and IZA \\ Kevin Y. Shih \\ UC Davis \\ Discussion Paper No. 7367 \\ April 2013 \\ IZA \\ P.O. Box 7240 \\ 53072 Bonn \\ Germany \\ Phone: +49-228-3894-0 \\ Fax: +49-228-3894-180 \\ E-mail: iza@iza.org
}

Any opinions expressed here are those of the author(s) and not those of IZA. Research published in this series may include views on policy, but the institute itself takes no institutional policy positions. The IZA research network is committed to the IZA Guiding Principles of Research Integrity.

The Institute for the Study of Labor (IZA) in Bonn is a local and virtual international research center and a place of communication between science, politics and business. IZA is an independent nonprofit organization supported by Deutsche Post Foundation. The center is associated with the University of Bonn and offers a stimulating research environment through its international network, workshops and conferences, data service, project support, research visits and doctoral program. IZA engages in (i) original and internationally competitive research in all fields of labor economics, (ii) development of policy concepts, and (iii) dissemination of research results and concepts to the interested public.

IZA Discussion Papers often represent preliminary work and are circulated to encourage discussion. Citation of such a paper should account for its provisional character. A revised version may be available directly from the author. 


\section{ABSTRACT}

\section{Foreign Scientists and Engineers and Economic Growth in Canadian Labor Markets}

In this paper we analyze the impact of foreign-born workers in the fields of Science, Technology, Engineering and Math (STEM) on employment and wages in Canadian geographical areas during the period 1991-2006. Canadian policies select immigrants with a strong emphasis on high educational attainment. Moreover the foreign-born constitute a third of the Canadian population making Canada a very good case to analyze the effect of foreignSTEM workers on the local economy. We use the dispersion of immigrants by nationality across 17 geographical areas in 1981 to predict the supply-driven increase in foreign Scientists and Engineers during the period 1991-2006. Then we analyze their impact on the employment and wages of college and non-college educated Canadian-born (native) workers. We find significant positive effects on the wages and (to a lesser extent) employment of college educated natives. We also find a smaller positive effect on the wages and employment of native workers with very low levels of education (i.e. those with no high school degree). This implies a positive productivity effect of foreign-STEM workers in Canada, and also a college bias in their contribution to productivity growth. Compared to the effect of foreign Scientists and Engineers in US cities, the Canadian results show similar effects on wages of college educated and at least partial evidence of a positive diffusion of the effect to non-college educated, which was not present in the US.

JEL Classification: J61, F22, O33, R10

Keywords: $\quad$ STEM workers, foreign-born, Canadian-born, college-educated, wage, employment

Corresponding author:

Giovanni Peri

Department of Economics

UC Davis

One Shields Avenue

Davis, CA 95616

USA

E-mail: gperi@ucdavis.edu 


\section{Introduction}

Scientists, Technology professional, Engineers, and Mathematicians, who we will call STEM workers or Scientists and Engineers for brevity, are the drivers of scientific and technological innovation and adoption ${ }^{1}$. Their presence in a local economy, such as a city, has been considered a main driver of productivity growth and economic success. Several studies (Rauch (1993), Moretti (2004a, 2004b), Iranzo and Peri (2009)) have emphasized the importance of a concentration of college educated workers in enhancing local productivity. Agglomeration of Scientists and Engineers generates agglomeration of productive industries (Ellison and Glaeser (1999)) that, in turn, generates local externalities and virtuous cycles of innovation (Jaffe et al. (1992), Saxenian (2002)) $)^{2}$.

Attracting highly educated workers, and especially scientists and engineers, has been considered as a key strategy to promote economic development and growth in cities and regions in many developed countries. Moreover, some countries consider attracting highly educated workers to be a key goal of their immigration policies. Canadian immigration policies of the last thirty years have been designed to attract scientists and engineers from the rest of the world by using a point system that favors foreign-born individuals with high levels of educational attainment and employment in some "specialty" occupations, among which scientists and engineers rank very highly ${ }^{3}$.

In this study we consider the inflow of foreign scientists and engineers in Canada and estimate their effect on employment, wages and rental prices at the local level. We isolate exogenous, supply-driven changes in foreign-born scientists and engineers in the period 19912006 by exploiting the unequal distribution of immigrants by nationality across Canadian geographical areas in 1981, and track their effects on wages, employment and rental costs for native-born (native) individuals across 17 geographical areas. Our identification strategy is similar to ones used by Card and Altonji (1991) and Card (2001) to identify the wage effect of immigrants, and is even more closely related to the one used in Kerr and Lincoln (2010) to estimate the effect of foreign scientists on U.S. patent applications ${ }^{4}$.

Foreign-STEM workers are likely to spur technological innovation and adoption in Canadian cities and regions, thereby improving average productivity. We analyze in detail who the beneficiaries of these productivity gains are. The development and adoption of new technologies - especially Information and Communication Technologies (ICTs) - is credited with significantly increasing the productivity and wages of college educated workers by enhancing and complementing their abilities, but also with increasing inequality-the demand for noncollege educated workers stagnates as ICTs substitute for their skills ${ }^{5}$. Hence our analysis

\footnotetext{
${ }^{1}$ See, among others, Zvi Griliches (1992) and Charles I. Jones (1995)

${ }^{2}$ Recent books by Edward Glaeser (2011) and Enrico Moretti (2012) identify a city's ability to innovate as the main engine of its growth.

${ }^{3}$ Green and Green (1995) document that the point system, created in 1967, altered the occupational composition of immigrant inflows away from low skilled workers and towards high skilled professionals. For a more recent overview of Canada's point system, see Beach et al. (2011).

${ }^{4}$ In a related paper (Peri, Shih and Sparber (2013)) we apply the same method to analyze the impact of STEM workers in US cities.

${ }^{5}$ See Katz and Murphy (1992), Krueger (1993), Autor, Katz, and Krueger (1998), Acemoglu (1998, 2002), Berman, Bound, and Griliches (1994), Autor, Levy, and Murnane (2003), and Autor, Katz, and Kerney (2006), among others. Several papers in this literature (e.g. Caselli (1999), Caselli and Coleman
} 
looks at the specific effects that foreign-STEM workers have on the wages and employment of native-STEM workers, native college educated workers and native non-college educated workers. We also analyze whether growth of foreign-STEM workers increases housing prices in local labor markets.

Our main finding is that a one percentage-point rise in the foreign-STEM share of total employment increased the wages of Canadian college educated workers by about 5 percentage-points, while it had a smaller and often non-significant effect on the wages of Canadian non-college educated workers. The same increase in foreign-STEM workers also had a positive and sometimes significant effect on the employment of college educated Canadians of around 0.5-0.7 percentage-points of total employment. The employment of noncollege educated was not affected.

Separating non-college educated into those with no degree and those with a high school degree we also find that foreign-STEM workers had a positive impact on the demand for the least educated group (high school dropouts), while the intermediate group (high school graduates) did not benefit from them. This finding implies that productivity growth driven by STEM workers may contribute to labor market polarization, increasing the relative demand for both manual/low skilled jobs performed by high school dropouts and high skilled jobs performed by college educated workers, but decreasing demand for routine jobs requiring intermediate skill levels (as argued by Autor, Levy and Murnane (2003)). Additionally, foreign-STEM workers also had a significantly positive impact on the housing costs of college educated workers, and insignificant effects on the employment and housing costs of non-college educated workers.

Finally, we compare these findings to estimates on the impact of foreign-STEM workers for US metropolitan areas found in Peri, Shih and Sparber (2013), and find that foreignSTEM workers had similarly positive productivity effects for college educated workers in the US and Canada. In contrast with the US, however, Canada exhibits some positive wage and employment effects that are diffused to non-college educated workers.

The rest of the paper is organized as follows. Section 2 describes the data, how STEM workers are defined, the construction of the supply-driven growth in foreign-STEM workers, and the identification strategy and power of the instrument. Section 3 presents the basic empirical estimates of the effect of an increase in foreign-STEM workers on the wages and employment of Canadian workers. In section 4 we extend the empirical analysis by looking at heterogeneity in the wage and employment effects of foreign-STEM on non-college educated, and by analyzing their impact on house rental prices. In section 5 we compare the Canadian estimates with those on foreign-STEM workers in the US, as found by Peri, Shih and Sparber (2013). Section 6 concludes.

(2006), and Goldin and Katz (2007)) emphasize that the large supply of college educated workers was itself the driver of the development of skill-biased technologies. Beaudry et al. (2010) and Lewis (2011) show the role of skill-supply in the adoption of specific technologies. Other papers (Beaudry and Greene $(2003,2005)$ and Krusell et al. (2000)) emphasize the role of capital (equipment) in increasing the productivity of highly educated workers. 


\section{Data and Empirical Methodology}

The source of all our data on occupations, employment, wages, rents, age, education, and nativity of individuals are provided by Statistics Canada. Specifically we use the Canadian Census Public Use Microdata File on Individuals (PUMFI) ${ }^{6}$ in 1981, 1991, 1996, 2001, and 2006. The 1981 PUMFI is a $2 \%$ sample and the $1991-2006$ files are roughly $3 \%$ samples $^{7}$. To protect the confidentiality of surveyed individuals, the Census Bureau re-coded PUMFI variables to highly aggregate resolutions. In particular, PUMFIs only identify an individual's province $^{8}$ of residence, and sometimes their Census Metropolitan Area (CMA) in regions with large populations, thereby greatly reducing the available geographic variation. Thus, the geographical level at which we can aggregate our data is constrained by the available geographic codes in the PUMFIs.

We use data on 17 geographic areas that can be consistently identified over the period 1981-2006. Fourteen of these are Metropolitan areas, including some large CMAs (Toronto, Montreal, Vancouver, Calgary, and Ottawa), and smaller CMAs (Quebec City, Hull, St. Catherines-Niagara, London, Hamilton, Winnipeg, Edmonton, Halifax, Kitchener). Then we also include provinces that have no identified CMAs and hence are considered as such (i.e. Saskatchewan, New Brunswick, and Newfoundland and Labrador). This concatenation of provinces and CMAs into geographic areas is largely due to data constraints, but does afford an interpretation of these geographic areas as labor markets. Metropolitan areas are compact economic units, and the three small provinces that we add can also be considered as relatively self-contained. In the remainder of the study we will refer to these 17 units "geographic areas" or "local labor markets".

\subsection{Summary Statistics on STEM workers}

The inflow of foreign-STEM workers during the period 1991-2006 was not homogeneously distributed across labor markets in Canada. This is because these locations, and their constituent industries and firms, varied widely in their dependence on foreign-STEM workers. Moreover immigrants had strong preferences to locate in certain cities and provinces particularly due to the existence of historical enclaves of immigrants of similar national origins. Differences in the density of foreigners across geographic areas in 1981 provide a dimension of supply-driven variation in the distribution of new foreign-STEM workers in the 1991-2006 period. Areas with many foreign-STEM workers in 1981 experienced large surges of STEM immigrants in the 1990's and 2000's. Places with low foreign-dependence, such as the Atlantic provinces and Northern territories, did not experience large surges. In the following sections we show the importance of the geographical dispersion of pre-existing immigrant enclaves as of 1981 in determining the net growth of foreign-STEM workers in later decades. We also check the validity of some identifying assumptions that are crucial for our approach,

\footnotetext{
${ }^{6}$ These microdata of the Canadian Census are the only ones available to non-Canadians.

${ }^{7}$ The file for 1991 is a $3 \%$ sample, the 1996 is a $2.8 \%$ sample, and the 2001 and 2006 are $2.7 \%$ samples

${ }^{8}$ Canada officially has 10 provinces: Alberta, British Columbia, Manitoba, New Brunswick, Newfoundland and Labrador, Nova Scotia, Ontario, Prince Edward Island, Quebec, and Saskatchewan. The PUMFI identifies these and defines an 11th province, which is the aggregation of the three territories: Northwest Territories, Nunavut, and Yukon.
} 
in particular that the distribution of native-STEM workers was quite different and unrelated to the distribution of foreign-STEM workers in 1981.

Before analyzing the geographic distribution of foreign-STEM workers and our index capturing supply-driven changes in foreign scientists and engineers, we present some aggregate statistics. As there is no official definition of a STEM worker we follow the procedure described here. We rank occupations on their intensity of employment with a post-secondary degree in a STEM field. ${ }^{9}$ Then we label as STEM occupations the top ranked in STEMmajor intensity that constitute around $10 \%$ of employment in each year. Thus, a STEM worker is an individual who works in one of these STEM occupations.

The first three columns of Table 1 show the foreign-born share of three different employment groups in Canada for each census year from 1981 to 2006. The following three columns show the corresponding values for the US, in the same years, keeping the definition of each group as similar as possible to the Canadian one. From left to right we show the percentage of foreign-born among all workers, among college educated workers and among workers in STEM occupations. Notice that, in both Canada and in the US, foreign-born are over-represented in STEM occupations relative to their average presence in employment. Moreover in both countries the percentage of foreign-born in STEM occupations increased enormously (more than three folds in Canada) between 1981 and 2006. As of 2006 almost one in three STEM workers in Canada was foreign-born, with the same ratio approximately equal to one in four in the US. An interesting difference between the US and Canada is that the Canadian immigration point-system generated an over-representation of foreign-born among college educated (33.7\% of them were foreign-born in 2006). In contrast, though US immigrants were not over-represented among college educated (as of 2006, 14.3\% of college educated were immigrants, a share close to one in total employment), they were over-represented among scientists and engineers, however. This was likely due to H1B visa policies, discussed in Peri et al. (2013), and because of the strong international appeal of US research institutions and STEM industries.

Table 2 shows the evolution over time of STEM workers and foreign-born STEM workers as a percentage of total employment in Canada. First notice that STEM occupations became more relevant in the overall employment of Canadian residents, as they accounted for $8.7 \%$ in 1981, while they employed $13.4 \%$ in 2006 . Even more remarkably, however, the share of foreign-born STEM workers grew from $0.7 \%$ to $4.2 \%$ of total employment, a six-fold increase. In fact since 1991 half of the net growth in STEM workers in Canada is attributable to inflows of foreign-born scientists and engineers. These aggregate numbers clearly show that foreigners contributed significantly to the growth of scientists and engineers in Canada. How can we measure the impact of these large inflows on the productivity of Canadian workers? We now turn to the geographic distribution of foreign-STEM in 1981 and its evolution over the following decades.

\footnotetext{
${ }^{9}$ Post-secondary majors are identifiable from 1991-2006 and STEM fields are defined as: Agricultural Science and Technologies, Engineering, applied sciences and related technologies/trades, Nursing and nursing assistance, Other health professions, and Mathematics and Physics.
} 


\subsection{Supply-driven increases in foreign-STEM workers across geo- graphic areas}

We construct a variable that captures the supply-driven increase of foreign-STEM workers in each of the 17 geographic areas between 1991 and 2006. We begin by defining the "dependence" of a geographic area on foreign-STEM workers from 11 specific foreign nationalities ${ }^{10}$. The dependence of area $c$ on foreign-STEM workers from a specific nationality $(n)$ in 1981 is defined as area $c$ 's share of foreign-STEM workers of that nationality in total employment: $\frac{S T E M_{c, 1981}^{F O R_{n}}}{E_{c, 1981}}$. The dependence of area $c$ on foreign-STEM workers overall is the sum of the dependence on each nationality group: $\frac{S T E M_{c, 1981}^{F O R}}{E_{c, 1981}}=\sum_{n=1}^{11}\left(\frac{S T E M_{c, 1981}^{F O R_{n}}}{E_{c, 1981}}\right)$. We choose 1981 because it is the earliest Canadian Census that allows the identification of the 17 geographic areas. It is also well before the period of analysis (which begins in 1991) and the distribution of scientists and engineers at that time was more likely to reflect the presence of traditional manufacturing sectors (oil, chemicals, nuclear) than the presence of the information and communication sector (ICT). In fact the ICT revolution that produced a surge in demand for STEM workers began later, during the 80's.

After constructing the STEM dependence of each geographic area in 1981 we calculate the aggregate growth factor, $g_{81-t}^{S T E M^{F O R_{n}}}$, of foreign-STEM workers for each nationality, $n$, in Canada between 1981 and year $t$ as,

$$
g_{81-t}^{S T E M^{F O R_{n}}}=\frac{S T E M_{t}^{F O R_{n}}}{S T E M_{1981}^{F O R_{n}}}
$$

where $S T E M_{t}^{F O R_{n}}$ in equation 1 is the total number of foreign-STEM workers of nationality, $n$, in Canada in year $t .^{11}$

In order to impute the number of foreign-STEM workers in city $c$ in year $t$ we then multiply the nationality-specific growth rates by the number of foreign-STEM workers of that nationality residing in city $c$ in 1981, $S T E M_{c 1981}^{F O R_{n}}$, and then sum over all nationalities as follows:

$$
\widehat{S T E M_{c t}^{F} O R}=\sum_{n=1}^{11} S T E M_{c 1981}^{F O R_{n}}\left(\frac{S T E M_{t}^{F O R_{n}}}{S T E M_{1981}^{F O R_{n}}}\right)=\sum_{n=1}^{11} S T E M_{c 1981}^{F O R_{n}}\left(g_{81-t}^{S T E M^{F O R_{n}}}\right)
$$

The supply-driven change in foreign-STEM workers, that we use as our instrumental variable in the main empirical specifications, is the change in $\widehat{S T E M_{c t}^{F} O R}$, defined above, over a half-decade standardized by the initial employment in the city $E_{c t}^{12}$ given as,

\footnotetext{
${ }^{10}$ The national groups are: USA, Germany, United Kingdom, Italy, Portugal, Poland, Rest of Europe, Asia, Africa, Rest of Americas, Other.

${ }^{11}$ Because PUMFIs did not identify detailed birthplace information in Atlantic Provinces and Northern territories, the growth rates are calculated net of foreign-STEM in these areas. Though this introduces some error, the error is very small as the share of all immigrants living in the Atlantic provinces and Northern territories is around $1 \%$ in each year of the sample.

${ }^{12}$ Since endogenous changes in total employment at the city level may affect the standardization, we also use imputed city employment, obtained using employment by native/foreign and college educated/non-
} 


$$
\frac{\Delta S T \widehat{E M_{c t}^{F} O R}}{E_{c t}}=\frac{\widehat{S T E M_{c t+5}^{F} O R}-S T \widehat{E M_{c t}^{F} O R}}{E_{c t}}
$$

The imputed increase in STEM workers captured by (3) does not depend on the areaspecific inflow of workers over the period 1991-2006 and hence is uncorrelated with areaspecific shocks that affected the productivity of local economy. Our imputed variable only depends on the distribution of foreign-STEM workers by nationality as of 1981, and on the aggregate inflow of foreign-STEM workers by nationality in Canada. This identification strategy is most closely related to the one used by Peri, Shih, and Sparber (2013), and is inspired by the previous works of Lincoln and Kerr (2011), Card (2001), and Altonji and Card (1991), among others.

In the next sections we seek to answer two questions. First: was the distribution of foreign-STEM workers in 1981 correlated with the overall STEM intensity of a city, which might have been correlated with subsequent increase in productivity? Second does our imputed variable have predictive power on $\frac{\triangle S T E M_{c t}^{F O R}}{E_{c t}}$, the actual change in foreign-STEM workers, as measured by Census data, standardized by total initial employment?

\subsection{Foreign-STEM and Native-STEM Dependence across geograph- ical areas in 1981}

Our identification strategy is based on the assumption that an area's dependence on foreignSTEM workers in 1981 varied across cites due to the differential presence of immigrants caused by persistent agglomeration of foreign communities. These differences subsequently affected the supply of foreign-STEM workers, but were not otherwise correlated with future technological and demand shocks that affected wages and employment. A particular challenge to this assumption might occur, for example, if the density of foreign-STEM workers was correlated with the productive and industrial structure of metropolitan areas in 1981-in terms of their sector composition and scientific and technological base-which would likely be correlated with future wage growth.

To partially address these concerns we show that the dependence of geographic areas on foreign-STEM workers in 1981 has essentially no correlation with their dependence on native-STEM workers. In 1981, more than 90\% of STEM workers were native-born Canadians. This implies that the overall dependence of a city on STEM workers in 1981, though correlated with the scientific and technological intensity of production, was not driven by foreign-STEM workers. Instead, foreign-STEM dependence was determined by the overall percentage of foreign-born residents in the area. We also show that while the dependence on foreign-STEM workers in 1981 is correlated with the imputed growth in STEM workers between 1991 and 2006, the 1981 dependence on native-STEM workers is not. In order to capture other province-specific features that might have affected the initial presence of foreign-born and the subsequent growth of a city we also include province-specific effects in

college educated status in 1981 augmented by the growth factor of national total employment, of each of these four groups. For example, $\hat{E}_{c t}^{F O R, \text { coll }}=E_{c 1981}^{F O R, \text { coll }}\left(E_{t}^{F O R, \text { coll }} / E_{1981}^{F O R, \text { coll }}\right)$. Thus, the denominator we use is: $E_{c t}=\hat{E}_{c t}^{F O R, c o l l}+\hat{E}_{c t}^{F O R, n o n-c o l l}+\hat{E}_{c t}^{N A T, \text { coll }}+\hat{E}_{c t}^{N A T, \text { non-coll }}$ 
several specifications. Our models are estimated in first differences so that effects are identified by half-decade changes in supply-driven foreign-STEM workers across geographic areas. This strategy should eliminate errors arising from unobserved area-specific determinants of the level of our outcome variables. However, we add to the rigor of our models by also including controls for eleven province-specific effects. Thus, identification relies on variation of growth rates across geographical areas within the same province.

The dependence on native and on foreign-STEM workers across the 17 Canadian geographic areas in 1981 varied substantially and these two variables had very little correlation with each other. The first two columns of Table 3 show no correlation between foreign- and native-STEM dependence across geographical areas. While only very limited inference can be drawn from 17 observations, the results suggest that foreign and native-STEM dependence across Canadian labor markets did not seem to have any correlation with each other in 1981. The OLS coefficient is very small, negative and insignificant at standard confidence levels. This suggests that foreign-STEM dependence had little to do with STEM intensity of a Canadian geographic area in 1981. Column 2 of Table 3 shows that a city's dependence on foreign-STEM workers in 1981 instead had more to do with the presence of other foreign-born residents as a share of the population. The foreign-born population share has an extremely significant association with its foreign-STEM dependence (F-statistic of 43.0) and explains about $74 \%$ of its cross-sectional variation. Hence areas with a large immigrant population had a large foreign-STEM dependence, while areas with large native-STEM sectors, potentially correlated with subsequent productivity growth, did not necessarily have large foreign-STEM dependence.

Column 3 of Table 3 goes on to show that the 1981 foreign-STEM dependence has significant power to predict the supply-driven increase in STEM across geographic areas (Fstatistic of 26.2 and the partial R-squared explained by that variable is 0.41 ). To the contrary, column 4 of Table 3 shows that the 1981 native-STEM dependence has no predictive power on the supply-driven increase in STEM (F-statistic of 1.58 and partial R-squared of 0.04). Areas with larger foreign-STEM-dependence in 1981 were not necessarily associated with high shares of STEM workers overall in 1981. However, the fact that large immigration flows produced significant increases in highly educated foreign-STEM workers during the 1990s and 2000s allowed these areas to increase the size of their STEM employment. The initial advantage in foreign-STEM dependence made these areas a more likely destination for foreign-STEM workers entering in 1991 and after. The presence of a network, the easier diffusion of information across foreign groups, and the familiarity of firms with foreign-STEM workers likely reduced the cost for foreign workers to locate in these areas.

Finally, we emphasize that our identification strategy relies upon more than just the overall foreign-STEM dependence. We also use the differential location of foreigners across Canadian areas depending on nationality. An initial foreign-STEM dependence on national groups that experienced large inflows (such as Asians) would produce a particularly large increase in STEM. Our method exploits this variation in the growth of STEM-immigrants from different nations. 


\subsection{Predicting the Increase in Foreign-STEM}

The first step in our empirical analysis is to establish that the imputed supply-driven growth of immigrant-STEM workers significantly predicts the actual increase in foreign-STEM workers across areas. The growth of foreign-STEM workers in a geographic area was driven in part by immigrant preferences, affected by the historical distribution of immigrants in 1981, but also by demand and productivity increases. In this section we analyze how the supplydriven increase in foreign-STEM affected the net observed increase in foreign-STEM workers across Canadian geographic areas. We estimate the following specification:

$$
\frac{\Delta S T E M_{c t}^{F O R}}{E_{c t}}=\phi_{t}+\phi_{p}+b_{1} \frac{\Delta \widehat{S T E M}_{c t}}{E_{c t}}+\varepsilon_{c t}
$$

The coefficient of interest is $b_{1}$ which measures the impact of imputed foreign-STEM inflows on the actual increase in foreign-STEM workers. The term $\phi_{t}$ captures two period fixed effects, and $\phi_{p}$ represents 11 province-fixed effects. We include $t=1991,1996,2001,2006$ so that the changes $\Delta$ refer to the periods 1991-1996, 1996-2001, and 2001-2006. $\varepsilon_{c t}$ is a zeromean random error uncorrelated with the explanatory variable.

In Table 4 we show estimates of the coefficient $b_{1}$ from different specifications. Columns 1 , 2 and 3 show the estimates of the coefficient $b_{1}$ in equation (4). In specification (1) we do not include any fixed effects. In (2) we include period fixed effects (this is the basic specification), and in (3) we include the more demanding province and period fixed effects. Considering that we only have 51 area by period observations the last specification that includes 13 fixed effects is very demanding. The effect of supply-driven STEM is always significant at the $5 \%$ level and its value is always close to one. This implies that an increase in supply-driven STEM immigrants by one percentage-point of employment increases actual foreign-STEM share of employment by one percentage-point. We can interpret this regression as the first stage in a two stage least squares (2SLS) estimate of the effect of STEM workers. Note that the F-statistic of 13.88 in the basic specification is well above the critical value for weak instrument tests (usually set around 10). Only when we include province-effects does the imputed variable (though still significant) become less powerful in predicting foreign-STEM (F-statistic equal to 4.91). Figure 1 provides the graphical representation of the power of the imputed variable in predicting the change in foreign-STEM. It shows a clear positive relation (t-statistic equal to 4.3) between the two variables. No outliers seem to drive this relationship.

In column 4 of Table 4 we explore whether the imputed foreign-STEM variable had a significant effect on the total increase in all STEM workers (including native workers). While less powerful than in predicting foreign-STEM, the imputed variable has a significant effect (at the 5\% level) also on the growth of total STEM workers (as percentage of the employment). The last column of Table 4 tests whether the predictive power of the imputed variable is affected by the inclusion of a control for the 1981 native-STEM dependence of the geographic area. We already documented in Table 2 a very weak correlation of nativeSTEM dependence in 1981 and subsequent foreign-STEM growth. Column 5 confirms that controlling for native-STEM dependence does not change at all the predictive power of the imputed variable. 


\section{The Estimated Effects of STEM workers on Wages and Employment}

In our empirical analysis we estimate the following specification in order to identify the effect of foreign-STEM workers on native labor market outcomes:

$$
y_{c t}^{N a t i v e, z}=\phi_{t}+\phi_{p}+b_{y, z} \frac{\Delta S T E M_{c t}^{F o r}}{E_{c t}}+b_{3} X_{c t}+\epsilon_{c t}
$$

The variable $y_{c t}^{\text {Native, } z}$ is an outcome for native workers of type $z$ (college-STEM, collegenon-STEM, or non-college) in geographic area $c$. In our analysis it measures either a change in wages or in employment. $\phi_{t}$ are period fixed effects, $\phi_{p}$ are province fixed effects, $X_{c t}$ are area-specific controls such as the dependence on native-STEM workers. The term $\frac{\Delta S T E M_{c t}^{F o r}}{E_{c t}}$ is the actual change in foreign-STEM and it is the main explanatory variable. We use the constructed $\frac{\triangle S T \widehat{E M}_{c t}^{F o r}}{E_{c t}}$ as an instrument when we perform the 2SLS estimates of equation (5). $\epsilon_{c t}$ is a zero-mean random error, and the coefficient of interest is $b_{y, z}$ which captures the impact of foreign-STEM on the outcome of interest $(y)$ relative to group $z$.

Each cell of Table 5 reports the $b_{y, z}$ estimates capturing the effects of foreign-STEM for different native outcomes, where each of the six columns represents a different outcome. In column 1 the dependent variable is the percentage change of the weekly wage paid to nativeSTEM workers $\left(\frac{\Delta w_{S T}^{\text {native }}}{w_{S T}^{\text {native }}}\right)$ in each of 17 geographic areas over the 1991-1996, 1996-2001, and 2001-2006 periods. In column 2 the dependent variable is the percentage change of the weekly wage of native college educated workers $\left(\frac{\Delta w_{\text {College }}^{\text {native }}}{w_{\text {College }}^{\text {Categ }}}\right)$, and in column 3 it is the percentage change of the weekly wage of native non-college educated workers $\left(\frac{\Delta w_{\text {nocollege }}^{\text {native }}}{w_{\text {Nocivollege }}^{\text {nate }}}\right){ }^{13}$. Columns 4,5 , and 6 show the effect of STEM on the change in employment of native-STEM workers, native college educated workers, and native non-college educated workers, as percentage of initial total employment $\left(\frac{\Delta S T E M_{c t}^{n a t}}{E_{c t}}, \frac{\Delta H_{c t}^{n a t}}{E_{c t}}\right.$, and $\frac{\Delta L_{c t}^{n a t}}{E_{c t}}$, respectively). The last column of Table 5 shows the Kleibergen-Paap F-statistics of the first stage that provides a sense of the strength of the instruments.

The different rows of Table 5 represent different specifications. Each includes period effects. The first row reports results from the basic specification. The second row specification is the same as the first but adds Province-effects. In the third row we perform a direct regression where we include the imputed foreign-STEM growth directly as an explanatory variable. Finally the fourth row shows the results of estimating equation (5) with OLS rather than 2SLS

Three important and consistent results emerge. First, there is a positive and significant effect of foreign-STEM workers on wages paid to Canadian college educated workers. The estimated effect is always statistically different from 0 at the $5 \%$ significance level, and the point estimates are between 2.8 and 6.4 percentage-points for each percentage-point increase in the STEM share of employment. The estimates of the effects on the wages of native-STEM workers are smaller and are only significant in two specifications. While native scientists and

\footnotetext{
${ }^{13}$ Weekly wages are defined as yearly wage income divided by the number of weeks worked. Employment includes all individual between 18 and 65 who have worked at least one week during the previous year.
} 
engineers may benefit from the same positive productivity effect of foreign-STEM as other highly educated natives, they may also be more exposed to direct competition from foreignSTEM workers, hence providing a possible explanation for their lower positive wage impacts. There is no evidence, however, either in the wage or in the employment specifications, of a displacement effect of foreign-STEM on native-STEM workers.

The second consistent result is that foreign-STEM workers also had a positive effect, although significant only in two specifications, on employment of native college educated workers. The point estimates of this effect are smaller than those on wages. They are consistent with the fact that an increase in productivity of highly educated in cities experiencing large inflows of foreign-STEM might have attracted more college educated natives in those cities.

The third important takeaway is that the inflow of foreign-STEM workers had generally a positive but not significant effect on wages and employment of non-college educated natives. In particular the point estimates of the wage response are positive, but are also imprecise and not statistically significant. The insignificant effect on non-college educated workers and the positive wage effect on college educated together suggest that foreign-STEM workers might have caused skill-biased productivity growth in Canadian geographical areas. The weak employment response of college employment might also suggest that adjustment mechanisms beyond the net inflow of college educated employment were at work such as changes in the price of non-tradeables (in the form of house rents), which we analyze in the next section.

Let us notice that the OLS estimates, reported in the last row of Table 5, show larger (and significant) employment effects of STEM immigrants on native college educated and nativeSTEM workers. To the contrary, the corresponding 2SLS (first row) do not confirm this finding. In part this is due to the less precise 2SLS estimates. However, the fact that there is a positive correlation in the employment of native-STEM and foreign-STEM, which does not seem causal, is very consistent with the presence of demand shocks in geographic areas. Positive technological shocks would attract both native and foreign-STEM workers and lead to upward-biased OLS estimates. However, when we isolate the supply-driven foreign-STEM changes, as we do when using the imputed STEM as instrument, the correlation with nativeSTEM employment turns out to be zero. The only effect that survives the instrumental variable approach is the one on the wage of college educated natives.

How large are the magnitudes of these estimated effects? The growth in foreign-STEM in the regressions is measured as a percentage of total initial employment. Foreign-STEM workers are a small group (between 0.7 and $4.2 \%$ of employment, as shown in Table 2). Their representation in total employment grew about 2 percentage-points during the period 1991-2006. Applying the 2SLS estimates of the first row in Table 5 to the average growth in foreign-STEM nationally implies that it produced an increase in inflation-adjusted wages of college educated natives of about 11 percentage-points. The same increase also produced a (non-significant) increase in wages of non-college educated of 5.8 percentage-points. These are substantial gains. If we consider that average real wage growth for college educated in Canada in the considered period (1991-2006) was 22 percentage points and for non-college educated was 8 percentage points ${ }^{14}$ we conclude that foreign scientists and engineers were major contributors to the growth of productivity in the Canadian economy.

\footnotetext{
${ }^{14}$ We calculated these values using weekly wages, deflated using the CPI, from the Canadian Census.
} 


\subsection{Robustness Checks}

Table 6 shows how robust the estimated effects are to different specifications and variable definitions. In particular we report the basic specification of Table 5 in the first row and then show the estimates from four different variations of the basic regression. The second row includes the dependence of the geographic areas on native-STEM workers in year 1981 as a control for the initial "technological intensity" of an area, as captured by the presence of scientists and engineers. The third row considers college educated immigrants (rather than STEM only) as the explanatory variable and uses an instrument adjusted accordingly. While we notice that the main estimated effects are still present, the magnitude of the coefficient on wages is smaller. If the actual drivers of productivity growth are STEM workers, measuring college educated, instead, would introduce an error and subsequent attenuation bias (dilution of the effect). This seems to be the case, as the estimated effect (2.87) is quite smaller than what found in any other specification that uses STEM workers (between 5.5 and 8.7).

In the specification of row four we control for the predicted inflow of less educated immigrants, also based on the distribution of less educated immigrants by nationality in year 1981. While immigrants in general may bring differentiated skills to the local labor markets and enhance their performance, our focus is on foreign Scientists and Engineers. Controlling for other (less educated) immigrants would isolate the effect of STEM immigrants only ${ }^{15}$. Notice that by controlling for the imputed inflow of non-college educated immigrants we reduce significantly the power of the instrument. This is because areas that had a large foreign-STEM dependence in 1981 also had a large community of non-college educated foreigners and hence the predictor of non-college educated immigrants is correlated with the predictor of STEM immigrants. The differences in the distribution of nationalities, however, between more and less educated is enough to provide the needed variation for identification. Finally in the fifth row we use total change in STEM workers as explanatory variable while still using the predicted foreign-STEM change as instrument. While the instrument is rather weak in this specification, the point estimates of the wage effects on STEM and college educated are close to those in the basic specification.

Taken as a whole the estimates of Table 6 confirm the robustness of the positive and significant estimated effect of foreign-STEM on wages of native college educated. The median estimated coefficient is around 5 which is very close to the estimate in the basic specification. The effects estimated on the wages of native-STEM workers are also positive and usually significant, but smaller (around 2 percentage-point increase for an inflow of foreign-STEM of one percentage of employment). The other effects are rarely significant, except for the employment effects on native college educated which are usually positive and significant in two specifications and close to 0.5. Finally the effects of foreign-STEM on the wages and employment of non-college educated are mostly positive but they rarely reach significance (only in the last row the wage effect is significant). It is worth looking more carefully at the effects on the group of non-college educated to see whether some subgroups within it benefitted while other lost. We explore this exercise in the next section.

\footnotetext{
${ }^{15}$ As additional check (not reported) we also control for non-STEM immigrants. The results show that non-STEM immigrants do not have any significant impact. The coefficients on STEM immigrants do not change by much, although the standard errors increase reducing the significance of the coefficients.
} 


\section{Extensions}

\subsection{Heterogeneous effects on the wages and employment of non- college educated}

Table 7 shows the effect of foreign-STEM workers on the wages (columns 1 and 2) and employment (columns 3 and 4) of native non-college educated workers. In this specifications we refine this educational category by separating non-college educated into high school dropouts (columns 2 and 4) and high school graduates (columns 1 and 3). By distinguishing high school graduates from high school dropouts we can check whether these two groups are differentiated in their complementarity with college educated labor.

This is also an interesting test for whether foreign-STEM workers produced the type of change in labor demand that has been defined as "polarization of the labor market". This phenomenon implies that higher employment growth at the high and low ends of the education spectrum have occurred at the expenses of intermediate-level jobs (e.g. Autor (2010), Autor et al. (2006)). Some studies (e.g. Autor, Levy and Murnane (2003)) have emphasized that one driver of this phenomenon was information technology, whose development and adoption was certainly facilitated by STEM workers. Technological innovation, the story goes, has substituted routine cognitive tasks typically performed by workers with a high school degree (e.g. data processing, and logistical, organizational and secretarial activities) with the computer. In contrast, however, this type of innovation did not decrease the demand for manual tasks in sectors as construction, personal, hospitality and home services typically performed by non-high school educated workers. Hence ICT innovation did not displace the lowest educated workers, and in fact may have even created new jobs in these occupations, as the college educated became richer and may have demanded more of these services.

The estimates of Table 7 show that STEM effects on high school graduates are insignificant (the point estimate is even negative for the employment effect). To the contrary the effects on wages and employment of high school dropouts are positive and significant. In particular an increase in foreign-STEM by one percentage of employment increases the wages of workers with no degree by 4.2 percentage-points, and their employment by 0.9 percent of total employment. This would be consistent with claims that STEM driven-technological progress contributes to labor market polarization by positively impacting the demand for low education groups (dropouts) more than intermediate education groups (high school graduates). This positive and significant effect on workers with no degree is an interesting sign that the benefits from STEM workers may diffuse in the local economy, via local demand, to workers not directly affected by the increases in productivity driven by information technology. Foreign scientists and engineers benefitted college graduates but also, possibly through local labor demand linkages, workers with low skill levels.

\subsection{The Effect on Housing Rents}

The estimated impact of foreign-STEM workers on wages paid to college educated natives is significantly positive. However the impact was smaller and less statistically significant on the employment of native college educated in Canadian Geographical areas. Why do we not 
see more college educated workers move to locations in which STEM workers have increased their productivity? A plausible explanation for the US, emphasized by Moretti (2011) and Saiz (2007), is that the cost of non-tradeable services, mainly housing rents, increased in cities experiencing wage growth. Thus, housing prices might absorb some of the college educated wage growth driven by an inflow of STEM workers that we have identified in this paper. We are not aware of similar studies on Canadian cities but it makes sense to think that a similar mechanism may be at work there too.

In order to check that this is a relevant adjustment channel we analyze the effect of STEM workers on house rents, as measured by the Canadian Census in 1991, 1996, 2001, and 2006. We construct the median monthly rent per room in constant dollars by using data on the total number of rooms occupied and rent paid by native individuals between 18 and 65 years of age in a geographic area (to be consistent with the wage data). In order to identify the specific effect for college and non-college educated rents we construct the rent per room of those two groups separately ${ }^{16}$.

We then adopt these median rent values as the $y$ outcome variable in regression (5), using the same methodology and instruments as in our wage and employment regressions. We include period effects in all specifications. Table 7 reports the estimated effect on a change in rents paid by college and non-college educated workers caused by changes in foreign-STEM employment. Columns 1 and 3 show the effect on the median rent paid by college educated workers (controlling or not for the initial native-STEM dependence in the area), while columns 2 and 4 show the impact on the median rent of non-college educated labor. In the first row we show 2SLS estimates of the specification. The last row shows the first stage F-statistics that reveals the strength of the instruments.

The main result we find is a positive and significant effect of foreign-STEM on rents paid by college educated workers. The point estimates are around 4. Conversely, point estimates of STEM effects on rents paid by non-college educated workers are smaller (near 2) and are not statistically significant. The inflow of foreign-STEM workers increased the wages of college educated labor but also increased their housing costs. This differential increase in rents is probably due to the more limited supply of desirable locations in geographic areas for college educated labor and the larger increase in their incomes.

Housing costs are likely to affect the cost of other non-tradeable local services as well, and the sum of those effects will influence real wages. The US Consumer Expenditure Surveys ${ }^{17}$ for college educated workers from 1998-2002 - dates in the middle of our dataset - shows that housing costs represented $33 \%$ of individual expenditures, while an additional $17 \%$ of their expenditures were in utilities, health, and entertainment (arguably non-tradeable services). Hence, $50 \%$ of college educated workers' incomes could easily be spent on nontradeable services. If we consider the average estimated price effect (from Table 11) to be around a 4 percentage-point increase for each one percentage-point rise in the STEM share of employment, and the corresponding average effect on wages to be around 5.5 percentage-

\footnotetext{
${ }^{16}$ We use median rent in the geographic area (rather than average rent) because payments are top-coded and in some metropolitan areas a large proportion of individuals are subject to the top-code. This would affect the average but not the median value of rents. We use the data on rents, rather than house values, because they capture more closely the cost of housing services provided by a building and do not include their asset value.

${ }^{17}$ See the Bureau of Labor Statistics (2005).
} 
points (from the basic specification in Table 5 ), then the real wage increase for college educated labor, accounting for purchasing power, would be only around 3.5 percentagepoints $^{18}$.

We then use the effects of foreign-STEM on native college educated real wages (equal to 3.5 from the calculation above), on native college educated employment (0.56 in the basic specification of Table 5), and the share of native college educated in total employment in 2001 (0.15) to derive the implied elasticity of labor supply for native college educated ${ }^{19}$. The implied value for the elasticity of labor supply (employment) of college educated natives to their own wage is $1.06(=0.56 /(3.5 * 0.15))$. This is a large value, yet close to estimates in several studies (e.g. Kimmel and Kniesner (1998)). It implies a large response of college educated employment to changes in wages, consistent with the idea that college educated workers are higly mobile across geographical areas. The STEM effect on non-tradeable prices, therefore, contributes substantially to absorbing the local effect on college educated wages. The response of college educated supply to changes in real wages is in line with several estimates in the previous literature.

\section{Comparison with the effects in US cities}

Overall Canadian labor markets seem to have benefitted significantly from the inflow of foreign-STEM workers. The growth of wages and employment for highly educated Canadians was stimulated by foreign-STEM workers. Even the job opportunities of less educated (those with no degree) seem to have improved because of these positive growth effects. The cost of housing, especially for the highly educated who are likely to live in the more expensive parts of town, increased. Are these positive effects of highly educated foreign scientists and engineers generalizable to other economies? Can we compare these effects with the impact of foreign scientists and engineers in other countries?

Table 9 shows the estimated effects for the basic specification estimated using Canadian data with a similar specification estimated by Peri, Shih and Sparber (2013) on US cities. The analysis of STEM workers in US cities relies on many more observations (219 cities over 20 years) and exploits the large inflows of the 1990's and 2000's driven by the H1B visa policy, explicitly designed to attract "specialty" workers and especially STEM workers. Nevertheless the empirical approach, the identification strategy and the period used in these two studies are similar, so that we can compare the estimates and learn if foreign-STEM workers had similar impact in these two countries.

The first row of Table 9 shows the basic estimated effects of foreign-STEM workers using Canadian geographical areas. The second row shows the basic estimated effects for US

\footnotetext{
${ }^{18}$ To calculate the effect on real wage, in percentage point we take the change in nominal wages in percentage points (5.5) and subtract the percentage point change in price of non-tradeables (4) times the share of non-tradeables in consumption (0.5). Hence: $3.5=5.5-0.5 *(4)$.

${ }^{19}$ The elasticity of labor supply of college educated to own wage is $\left(\Delta H_{c t}^{\text {nat }} / H_{c t}^{\text {nat }}\right) /\left(\Delta w_{\text {College }}^{\text {native }} / w_{\text {College }}^{\text {native }}\right)$.From our empirical analysis we obtain the following estimated responses: $b_{w, H}=\left(\Delta w_{\text {College }}^{\text {native }} / w_{\text {College }}^{\text {native }}\right) /\left(\Delta S T_{c t}^{F O R} / E_{c t}\right)$ and $b_{\text {empl }, H}=\left(\Delta H_{c t}^{\text {nat }} / E_{c t}\right) /\left(\Delta S T_{c t}^{F O R} / E_{c t}\right)$ so we can convert them into the elasticity of labor supply of college educated with the following formula: $\left(b_{e m p l, H} / b_{w, H}\right) *\left(H_{c t}^{n a t} / E_{c t}\right)^{-1}$ where $H_{c t}^{n a t} / E_{c t}$ is the share of native college educated in total employment.
} 
metropolitan areas. One common result is that the effect on college educated natives is significant and similar in the two cases (coefficient around 5). However the US shows a positive and stronger effect for native-STEM wages, but non-significant and negative point estimates on the wages and employment of non college educated. In Peri, Shih and Sparber (2013) we also separate workers with no degree and high school graduate and find no significant effect on wage or employment either group. Somewhat differently, however, the Canadian data show a positive albeit not significant effect of STEM on wage and employment of non-college educated. The split between workers with no degree and High school graduates (in Table 7), moreover, shows that the least educated group received a positive demand boost from the inflow of foreign-STEM workers.

Overall, while the productivity effect on college educated seems similar between Canada and the US, there seems to be lower skill-bias in the Canadian effect as the estimated effect on wages and employment of non-college educated is never negative, and the employment and wages of workers with no degree seem to respond positively to foreign-STEM. Perhaps the productive and/or institutional structure of the Canadian economy is more conducive to a broader diffusion of the positive productivity effect of scientist and engineers on the rest of the labor force.

\section{Discussion and Conclusions}

The design of Canada's immigration policy has helped to generate large inflows of scientists and engineers over the past few decades. In this paper we estimate the impact of inflows of foreign scientists and engineers on the productivity of native-born college and non-college educated Canadian workers. The uneven distribution of foreign-STEM workers across Canadian provinces and metropolitan areas in 1981 - a decade prior to our period of analysis - and the high correlation between the pre-existing enclaves of foreign-born workers and subsequent immigration allows us to identify a supply-driven inflow in foreign-STEM workers. We find that a one percentage-point increase in the foreign-STEM share of an area's total employment over five years increased wages of native college educated workers by 5 percentage-points and also had a small positive effect on their employment. These results indicate that growth in STEM workers spurred technological growth by increasing the productivity of (and demand for) college educated workers.

The inflow of foreign scientists and engineers also had (often non-significant) small positive effects on the wages and employment of non-college educated labor. After analyzing the group of non-college educated laborers in more detail we find that workers with less than a high school degree, who are typically employed in manual-intensive local services, received a positive boost in employment and wages from the local inflow of foreign-STEM. In contrast we find no impacts on the wages or employment of middle-skill workers (non-college educated with a high school degree). These results suggest that foreign-STEM inflows may have contributed to polarization in Canadian labor markets, similar to the recently documented labor market polarization in the US (e.g. Autor (2010), Autor et al. (2006)).

The increased incomes of college educated workers also produced higher demand for local, non traded goods. This is evidenced by increased housing rents, especially for college educated workers, which eroded the purchasing power of their wage gains. Increased demand 
for local non tradeables also increased the wages of less educated workers who provide such services. Native workers as a whole benefitted significantly from the inflow of foreign-STEM workers which increased wages of college educated by 11 percentage-points over the period 1991-2006.

While Canada's immigration policy is selective of high skilled workers, understanding more about the quality of such workers remains an important task. In this paper we do not discuss heterogeneity in the quality of foreign-STEM workers. Indeed the positive productivity effects we find may likely depend on the quality of foreign scientists and engineers, for example, whether they obtained their degree in Canada and how this is related to their economic contributions. Understanding the quality and human capital of immigrants, and the interaction of their quality with measured productivity effects in greater detail is an important future avenue of research. 


\section{References}

[1] Acemoglu, Daron. (1998). "Why Do New Technologies Complement Skills? Directed Technical Change and Wage Inequality." The Quarterly Journal of Economics 113(4): November 1998, pp. 1055-89.

[2] Acemoglu, Daron. (2002). "Technical Change, Inequality and the Labor Market." Journal of Economic Literature 40(1): March 2002, p. 7-72.

[3] Acemoglu, Daron, and Joshua Angrist. (2000). "How large are human capital externalities? Evidence from Compulsory Schooling Laws." NBER Macroeconomics Annual, 2000 .

[4] Altonji, Joseph G., and David Card. (1991). "The Effects of Immigration on the Labor Market Outcomes of Less-Skilled Natives." In, John M. Abowd and Richard B. Freeman, eds., Immigration, Trade, and the Labor Market. Chicago: University of Chicago Press, 1991, pp. 201-34.

[5] Autor, David H. (2010). "The Polarization of Job opportunities in the U.S. Labor Market" The Hamilton Project, Washington D.C. April 2010.

[6] Autor, David H., Frank Levy, and Richard J. Murnane. (2003). "The Skill Content of Recent Technological Change: An Empirical Exploration," The Quarterly Journal of Economics 118(4): November 2003, pp. 1279-1334.

[7] Autor, David H., Lawrence F. Katz and Alan Krueger. (1998). "Computing Inequality: Have Computers Changed the Labor Market?" The Quarterly Journal of Economics 113(4): November 1998, pp. 1169-1214.

[8] Autor, David H., Lawrence F. Katz, and Melissa S. Kearney. (2006). "The Polarization of the U.S. Labor Market." The American Economic Review 96(2): May 2006, pp. 189-194.

[9] Beach, Charles M., Christopher Worswick, and Alan G. Green. (2011). "Toward Improving Canada's Skilled Immigration Policy: An Evaluation Approach " C.D. Howe Institute Policy Studies

[10] Beaudry, Paul, and David A. Green. (2003). "Wages and Employment in the United States and Germany: What Explains the Differences?" The American Economic Review 93(3): June 2003, pp. 573-602.

[11] Beaudry, Paul, and David A. Green. (2005). "Changes in U.S. Wages, 1976-2000: Ongoing Skill Bias or Major Technological Change?" Journal of Labor Economics 23(3), July 2005, pp. 609-648.

[12] Beaudry, Paul, Mark Doms and Ethan Lewis. (2010). "Should the PC be Considered a Technological Revolution? Evidence from U.S. Metropolitan Areas." Journal of Political Economy 118(5): October 2010, pp. 988-1036. 
[13] Berman, Eli, John Bound and Zvi Griliches. (1994). "Changes in the Demand for Skilled Labor within U.S. Manufacturing: Evidence from the Annual Survey of Manufactures." The Quarterly Journal Of Economics 109(2): May 1994, pp. 367-397.

[14] Bureau of Labor Statistics. (2005). "The Consumer Expenditure Survey" years 19992002, http://www.bls.gov/cex/home.htm\#tables.

[15] Card, David. (2001). "Immigrant Inflows, Native Outflows, and the Local Labor Market Impacts of Higher Immigration." Journal of Labor Economics 19(1): January 2001, pp. $22-64$.

[16] Caselli, Francesco. (1999). "Technological Revolutions," The American Economic Review, 89(1): March 1999, pp. 78-102.

[17] Caselli, Francesco and Wilbur John Coleman II. (2006). "The World Technology Frontier." American Economic Review 96(3): June 2006, pp. 499-522.

[18] Ellison, Glenn and Edward L. Glaeser. (1999). "The Geographic Concentration of Industry: Does Natural Advantage Explain Agglomeration?," American Economic Review, American Economic Association, vol. 89(2), pages 311-316, May.

[19] Glaeser, Edward L. (2011). "The Triumph of the City: How Our Greatest Invention Makes Us Richer, Smarter, Greener, Healthier, and Happier" New York: Penguin Press (2011)

[20] Goldin, Claudia, and Lawrence F. Katz. (2007). "Long-Run Changes in the Wage Structure: Narrowing, Widening, Polarizing." Brookings Papers on Economic Activity. 2007 (2):135-65

[21] Green, Alan G., and David A. Green. (1995). "Canadian immigration policy: The effectiveness of the point system and other instruments." Canadian Journal of Economics. 28(4b): 1006-41

[22] Griliches, Z. (1992). "The Search for R\&D Spillovers" Scandinavian Journal of Economics. Vol. 94(0), pp. 29-47.

[23] Iranzo, Susana and Giovanni Peri. (2009). "Schooling Externalities, Technology, and Productivity: Theory and Evidence from U.S. States." Review of Economics and Statistics 91(2): May 2009, pp. 420-431.

[24] Jaffe, Adam B., Manuel Trajtenberg, Rebecca Henderson. (1993). "Geographic Localization of Knowledge Spillovers as Evidenced by Patent Citations." The Quarterly Journal of Economics 108 (3): August 1993, pp. 577-598.1.

[25] Jones, C. (1995). "Time Series tests of Endogenous Growth Models" Quarterly Journal of Economics, Vol.110. pp.495-525.

[26] Katz, Lawrence F. and Kevin M. Murphy. (1992). "Changes in Relative Wages, 19631987: Supply and Demand Factors." The Quarterly Journal of Economics 107(1): February 1992, pp. 35-78. 
[27] Kerr, William and William F. Lincoln. (2010). "The Supply Side of Innovation: H1B Visa Reforms and U.S. Ethnic Invention." Journal of Labor Economics 28(3): 2010, p. 473-508.

[28] Kimmel Jean and Thomas J. Kniesner. (1998). "New Evidence on Labor Supply: Employment versus Hours elasticities by Sex and Marital Status" Journal of Monetary Theory 42(2): 289-301.

[29] Krueger, Alan. (1993). "How Computers Have Changed the Wage Structure: Evidence from Microdata 1984-1989." The Quarterly Journal of Economics 108(1), February 1993, pp. 33-60.

[30] Krusell, Per, Lee E. Ohanian, Jose-Victor Rios-Rull, and Giovanni L. Violante. (2000) "Capital-Skill Complementarity and Inequality: A Macroeconomic Analysis," Econometrica 68(5), September 2000, pp. 1029-1053.

[31] Lewis, Ethan. (2011). "Immigration, Skill Mix, and Capital-Skill Complementarity", Quarterly Journal of Economics 126(2): May 2011, pp. 1029-1069.

[32] Moretti, Enrico. (2004a). "Estimating the Social Return to Higher Education: Evidence from Longitudinal and Repeated Cross-Sectional Data." Journal of Econometrics 121 (1): 2004a, pp. 175-212.

[33] Moretti, Enrico. (2004b). "Workers' Education, Spillovers and Productivity: Evidence from Plant-Level Production Functions." American Economic Review 94(3) pp. 656-690.

[34] Moretti, Enrico. (2011). "Local Labor Markets" Volume 4 of the Handbook of Labor Economics, Chapter 14, pp. 1237-1313.

[35] Moretti, Enrico. (2012). "The New Geography of Jobs" Houghton Miffin Harcourt Publishing Company, New York NY.

[36] Peri, Giovanni, Kevin Y. Shih and and Chad Sparber. (2013). "STEM Workers, H1B Visas and Productivity in US Cities," Norface Discussion Paper Series 2013/009, Norface Research Programme on Migration, Department of Economics, University College London.

[37] Rauch, James E. (1993). "Productivity Gains from Geographic Concentration of Human Capital: Evidence from the Cities," Journal of Urban Economics, Elsevier, vol. 34(3), pages 380-400, November.

[38] Saiz, Albert. (2007). "Immigration and housing rents in American cities," Journal of Urban Economics, Elsevier, vol. 61(2), pages 345-371.

[39] Saxenian, Anna Lee. (2002). "Silicon Valley's New Immigrant High Growth Entrepreneurs." Economic Development Quarterly 16(1): February 2002, p. 20-31. 


\section{Tables and Figures}

Table 1: Summary Statistics, Percentage of Foreign-Born, by Group in Canada and in the US

\begin{tabular}{cccc|ccc}
\hline \multicolumn{3}{c}{ Canada } & \multicolumn{3}{c}{ United States } \\
\hline $\begin{array}{c}\text { Foreign-Born \% } \\
\text { of Employment }\end{array}$ & $\begin{array}{c}\text { Foreign-Born } \\
\text { \% of College- } \\
\text { Educated }\end{array}$ & $\begin{array}{c}\text { Foreign-Born } \\
\text { \% of STEM } \\
\text { workers }\end{array}$ & $\begin{array}{c}\text { Foreign-Born } \\
\text { \% of } \\
\text { Employment }\end{array}$ & $\begin{array}{c}\text { Foreign-Born } \\
\text { \% of College- } \\
\text { Educated }\end{array}$ & $\begin{array}{c}\text { Foreign-Born } \\
\text { \% of STEM } \\
\text { workers }\end{array}$ \\
\hline $\mathbf{1 9 8 1}$ & $8.2 \%$ & $8.5 \%$ & $8.2 \%$ & $6.4 \%$ & $7.0 \%$ & $9.8 \%$ \\
\hline $\mathbf{1 9 9 1}$ & $\mathbf{2 3 . 6 \%}$ & $\mathbf{2 6 . 8 \%}$ & $\mathbf{2 5 . 5 \%}$ & $9.0 \%$ & $9.0 \%$ & $13.7 \%$ \\
\hline $\mathbf{1 9 9 6}$ & $24.0 \%$ & $27.5 \%$ & $26.7 \%$ & $11.1 \%$ & $10.8 \%$ & $16.6 \%$ \\
\hline $\mathbf{2 0 0 1}$ & $25.2 \%$ & $30.7 \%$ & $29.3 \%$ & $13.2 \%$ & $12.7 \%$ & $19.5 \%$ \\
\hline $\mathbf{2 0 0 6}$ & $26.3 \%$ & $33.7 \%$ & $31.4 \%$ & $15.0 \%$ & $14.3 \%$ & $22.5 \%$ \\
\hline
\end{tabular}

Note: The figures are obtained by the authors from PUMFI Canadian Census and IPUMS USA data. The relevant population includes only non-institutionalized individuals between age 18 and 65 who have worked at least one week in the previous year. 
Table 2

\section{STEM Workers as a Percentage of Employment, Canada}

\begin{tabular}{lcc}
\hline & Foreign-STEM & Total STEM \\
\hline $\mathbf{1 9 8 1}$ & $0.7 \%$ & $8.7 \%$ \\
\hline $\mathbf{1 9 9 1}$ & $2.5 \%$ & $9.9 \%$ \\
\hline $\mathbf{1 9 9 6}$ & $2.9 \%$ & $10.9 \%$ \\
\hline $\mathbf{2 0 0 1}$ & $3.7 \%$ & $12.9 \%$ \\
\hline $\mathbf{2 0 0 6}$ & $4.2 \%$ & $13.4 \%$ \\
\hline
\end{tabular}

Note: The figures are obtained by the authors from PUMFI Canadian Census data. The relevant population includes only non-institutionalized individuals between age 18 and 65 who have worked at least one week in the previous year. 
Table 3

Native and Foreign STEM Dependence across Canadian Geographic areas in 1981

\begin{tabular}{|c|c|c|c|c|}
\hline & $\begin{array}{c}(1) \\
\text { Foreign-Stem } \\
\text { Dependence } \\
1981\end{array}$ & $\begin{array}{c}12) \\
\text { Foreign-Stem } \\
\text { Dependence } \\
1981\end{array}$ & $\begin{array}{l}\text { (3) } \\
\text { Predicted foreign } \\
\text { STEM Growth }\end{array}$ & $\begin{array}{l}\text { (4) } \\
\text { Predicted foreign } \\
\text { STEM Growth }\end{array}$ \\
\hline $\begin{array}{l}\text { Foreign-STEM } \\
\text { Dependence, } 1981\end{array}$ & & & $\begin{array}{c}0.16^{* * *} \\
(0.03)\end{array}$ & \\
\hline $\begin{array}{l}\text { Native STEM Dependence, } \\
1981\end{array}$ & $\begin{array}{l}-0.001 \\
(0.06) \\
\end{array}$ & & & $\begin{array}{l}-0.041 \\
(0.032) \\
\end{array}$ \\
\hline $\begin{array}{l}\text { Foreign-Born Share of } \\
\text { Population, } 1981\end{array}$ & & $\begin{array}{c}0.074^{* * *} \\
(0.011) \\
\end{array}$ & & \\
\hline Observations & 17 & 17 & 51 & 51 \\
\hline F-Statistic & 0.01 & 43.01 & 26.2 & 1.58 \\
\hline R-Square & 0.00 & 0.74 & 0.41 & 0.04 \\
\hline
\end{tabular}

Note: Each column represents a separate regression. The dependent variable is written at the top of the corresponding column. Specifications (1) and (2) include Canadian Metro areas/Provinces in 1981. Regressions (3) and (4) include the predicted change in foreign STEM in 1991-96, 1996-2001 and 2001-2006 regressed on the 1981 STEM dependence (foreign or native). The standard errors are heteroskedasticity robust

$* * *, * *, *=$ significant at the $1 \%, 5 \%$ and $10 \%$ level. 
Table 4

Predictive Power of the Imputed Increase in Foreign-STEM

Panel of 17 Canadian geographic areas 1991-1996, 1996-2001, 2001-2006

\begin{tabular}{|c|c|c|c|c|c|}
\hline $\begin{array}{l}\text { Dependent } \\
\text { Variable }\end{array}$ & $\begin{array}{c}\text { (1) } \\
\text { Change in } \\
\text { Foreign-STEM } \\
\text { as a \% of Initial } \\
\text { Employment }\end{array}$ & $\begin{array}{c}\text { (2) } \\
\text { Change in } \\
\text { Foreign-STEM } \\
\text { as a \% of Initial } \\
\text { Employment }\end{array}$ & $\begin{array}{c}\text { (3) } \\
\text { Change in } \\
\text { Foreign-STEM } \\
\text { as a \% of } \\
\text { Initial } \\
\text { Employment }\end{array}$ & $\begin{array}{c}\text { (4) } \\
\text { Change in } \\
\text { total STEM as } \\
\text { a \% of Initial } \\
\text { Employment }\end{array}$ & $\begin{array}{c}\text { (5) } \\
\text { Change in } \\
\text { Foreign-STEM as } \\
\text { a \% of Initial } \\
\text { Employment }\end{array}$ \\
\hline Other Notes: & & & & & $\begin{array}{c}\text { Control for } 1981 \\
\text { Native Stem } \\
\text { Dependence }\end{array}$ \\
\hline $\begin{array}{l}\text { Imputed Change } \\
\text { in Foreign-STEM }\end{array}$ & $\begin{array}{c}1.01 * * * \\
(0.23)\end{array}$ & $\begin{array}{c}1.16 * * * \\
(0.31)\end{array}$ & $\begin{array}{l}1.28 * * \\
(0.57)\end{array}$ & $\begin{array}{l}1.34 * * \\
(0.61)\end{array}$ & $\begin{array}{c}1.16 * * * \\
(0.30)\end{array}$ \\
\hline Observations & 51 & 51 & 51 & 51 & 51 \\
\hline Period Effects & No & Yes & Yes & Yes & Yes \\
\hline Province Effects & No & No & Yes & No & No \\
\hline $\begin{array}{l}\text { F-test of the } \\
\text { Coefficient }\end{array}$ & 18.31 & 13.88 & 4.91 & 4.79 & 14.05 \\
\hline
\end{tabular}

Note: Each column reports coefficients from a separate regression. The units of observations are 17 Canadian Metro Areas/ Provinces over the periods 1991-1996, 1996-2001, 2001-2006. The dependent variable is described at the top of the column. The explanatory variable is always the imputed growth of foreign-STEM workers, as a percentage of initial employment. $* * *, * * *=$ significant at $1 \%, 5 \%$ and $10 \%$ level respectively. 


\section{Table 5}

\section{Estimated Effects of Foreign STEM on the Wages \& Employment of Canadian Native Workers}

Panel of 17 Canadian geographic areas 1991-1996, 1996-2001, 2001-2006

\begin{tabular}{|c|c|c|c|c|c|c|c|}
\hline $\begin{array}{l}\text { Explanatory Variable: } \\
\text { Imputed Growth in } \\
\text { Foreign-STEM }\end{array}$ & $\begin{array}{c}(1) \\
\text { Growth Rate } \\
\text { in Weekly } \\
\text { Wage, Native } \\
\text { STEM }\end{array}$ & $\begin{array}{c}\text { (2) } \\
\text { Growth Rate } \\
\text { in Weekly } \\
\text { Wage, } \\
\text { Native } \\
\text { College- } \\
\text { Educated }\end{array}$ & $\begin{array}{c}\text { (3) } \\
\text { Growth } \\
\text { Rate in } \\
\text { Weekly } \\
\text { Wage, } \\
\text { Native Non- } \\
\text { College- } \\
\text { Educated }\end{array}$ & $\begin{array}{c}\text { (4) } \\
\text { Growth Rate } \\
\text { in } \\
\text { Employment, } \\
\text { Native STEM }\end{array}$ & $\begin{array}{c}\text { (5) } \\
\text { Growth rate } \\
\text { in } \\
\text { Employment, } \\
\text { Native } \\
\text { College- } \\
\text { Educated }\end{array}$ & $\begin{array}{c}\text { (6) } \\
\text { Growth Rate } \\
\text { in } \\
\text { Employment, } \\
\text { Native Non- } \\
\text { College- } \\
\text { Educated }\end{array}$ & $\begin{array}{l}\text { K-P Wald F- } \\
\text { Statistic of } \\
\text { the First } \\
\text { Stage }\end{array}$ \\
\hline $\begin{array}{l}\text { Basic Specification, with } \\
\text { period effects }\end{array}$ & $\begin{array}{l}2.28^{*} \\
(1.30) \\
\end{array}$ & $\begin{array}{l}5.52^{* *} \\
(2.64) \\
\end{array}$ & $\begin{array}{c}2.97 \\
(1.92) \\
\end{array}$ & $\begin{array}{c}0.14 \\
(0.35)\end{array}$ & $\begin{array}{c}0.56 \\
(0.40) \\
\end{array}$ & $\begin{array}{c}0.42 \\
(1.77) \\
\end{array}$ & 13.87 \\
\hline $\begin{array}{l}\text { Specification, with } \\
\text { period and province } \\
\text { fixed effects }\end{array}$ & $\begin{array}{l}-1.08 \\
(1.67)\end{array}$ & $\begin{array}{c}2.86^{* *} \\
(1.20)\end{array}$ & $\begin{array}{c}0.54 \\
(0.84)\end{array}$ & $\begin{array}{c}0.06 \\
(0.33)\end{array}$ & $\begin{array}{l}0.78^{* *} \\
(0.32)\end{array}$ & $\begin{array}{l}-1.19 \\
(0.84)\end{array}$ & 4.91 \\
\hline $\begin{array}{l}\text { Basic Specification, } \\
\text { direct regression on } \\
\text { imputed foreign STEM } \\
\text { growth }\end{array}$ & $\begin{array}{l}2.66^{*} \\
(1.19)\end{array}$ & $\begin{array}{l}6.44^{* *} \\
(2.85)\end{array}$ & $\begin{array}{l}3.47 \\
(2.10)\end{array}$ & $\begin{array}{c}0.17 \\
(0.46)\end{array}$ & $\begin{array}{c}0.65 \\
(0.55)\end{array}$ & $\begin{array}{c}0.49 \\
(2.24)\end{array}$ & NA \\
\hline Basic Specification, OLS & $\begin{array}{c}1.28 \\
(1.10)\end{array}$ & $\begin{array}{c}4.10 * * \\
(1.77)\end{array}$ & $\begin{array}{c}1.65 \\
(1.25)\end{array}$ & $\begin{array}{c}0.34^{* *} \\
(0.17)\end{array}$ & $\begin{array}{c}0.64 * * \\
(0.24)\end{array}$ & $\begin{array}{c}0.48 \\
(1.12)\end{array}$ & NA \\
\hline
\end{tabular}

Note: Each cell includes the 2SLS estimate of the impact of growth of foreign-STEM on the dependent variable listed at the top of the column. The instrument used is the imputed growth of foreign- STEM workers. The last two rows use OLS estimation. The Basic specification estimated is as (5) in the text. It includes period effects. The standard errors are heteroskedasticity-robust and clustered at the province level. ***, **, * significant at the $1,5,10 \%$ level. 


\section{Table 6}

Foreign STEM Effect on the Wages \& Employment: Extensions and Checks

Panel of 17 Canadian geographic areas 1991-1996, 1996-2001, 2001-2006

\begin{tabular}{|c|c|c|c|c|c|c|c|}
\hline & & & Depende & tt Variable: Gro & vth Rate of & & \\
\hline $\begin{array}{l}\text { Explanatory Variable: } \\
\text { Growth rate of Foreign - } \\
\text { STEM } \\
\text { Instrument: Imputed } \\
\text { Growth of Foreign-STEM }\end{array}$ & $\begin{array}{c}\text { (1) } \\
\text { Weekly } \\
\text { Wage, } \\
\text { Native STEM }\end{array}$ & $\begin{array}{c}\text { (2) } \\
\text { Weekly Wage, } \\
\text { Native } \\
\text { College- } \\
\text { Educated }\end{array}$ & $\begin{array}{c}\text { (3) } \\
\text { Weekly Wage, } \\
\text { Native non- } \\
\text { College- } \\
\text { Educated }\end{array}$ & $\begin{array}{c}\text { (4) } \\
\text { Employment, } \\
\text { Native STEM }\end{array}$ & $\begin{array}{l}\text { (5) } \\
\text { Employment, } \\
\text { Native College- } \\
\text { Educated }\end{array}$ & $\begin{array}{c}\text { (6) } \\
\text { Employment, } \\
\text { Native Non- } \\
\text { College- } \\
\text { Educated }\end{array}$ & $\begin{array}{l}\text { K-P Wald F- } \\
\text { Statistic of } \\
\text { the First } \\
\text { Stage }\end{array}$ \\
\hline $\begin{array}{l}\text { Basic Specification, with } \\
\text { period effects }\end{array}$ & $\begin{array}{l}2.28 * \\
(1.30)\end{array}$ & $\begin{array}{l}5.52 * * \\
(2.64)\end{array}$ & $\begin{array}{c}2.97 \\
(1.92)\end{array}$ & $\begin{array}{c}0.14 \\
(0.35)\end{array}$ & $\begin{array}{l}0.56 \\
(0.40)\end{array}$ & $\begin{array}{c}0.42 \\
(1.77)\end{array}$ & 13.87 \\
\hline $\begin{array}{l}\text { Controlling for Native } \\
\text { STEM dependence } 1981\end{array}$ & $\begin{array}{l}2.27^{*} \\
(1.31) \\
\end{array}$ & $\begin{array}{l}5.55^{* *} \\
(2.67) \\
\end{array}$ & $\begin{array}{c}2.96 \\
(1.86) \\
\end{array}$ & $\begin{array}{c}0.13 \\
(0.18) \\
\end{array}$ & $\begin{array}{l}0.54^{* *} \\
(0.27) \\
\end{array}$ & $\begin{array}{c}0.39 \\
(1.63) \\
\end{array}$ & 14.04 \\
\hline $\begin{array}{l}\text { Independent variable: } \\
\text { foreign College educated }\end{array}$ & $\begin{array}{l}1.45^{*} \\
(0.88)\end{array}$ & $\begin{array}{l}2.87^{*} \\
(1.55) \\
\end{array}$ & $\begin{array}{c}1.30 \\
(1.09)\end{array}$ & $\begin{array}{c}0.03 \\
(0.16) \\
\end{array}$ & $\begin{array}{c}0.25 \\
(0.19)\end{array}$ & $\begin{array}{c}0.12 \\
(0.85)\end{array}$ & 87.91 \\
\hline $\begin{array}{l}\text { Basic, Controlling for less } \\
\text { educated immigrants (period } \\
\text { effects only) }\end{array}$ & $\begin{array}{l}2.47 \\
(1.82)\end{array}$ & $\begin{array}{l}6.91^{*} \\
(3.19)\end{array}$ & $\begin{array}{l}2.98 \\
(1.86)\end{array}$ & $\begin{array}{l}-0.18 \\
(0.36)\end{array}$ & $\begin{array}{l}-0.06 \\
(0.64)\end{array}$ & $\begin{array}{l}0.55 \\
(1.65)\end{array}$ & 10.96 \\
\hline $\begin{array}{l}\text { Total change in STEM as } \\
\text { explanatory variable }\end{array}$ & $\begin{array}{l}1.98^{*} \\
(1.05)\end{array}$ & $\begin{array}{l}4.80 * * \\
(1.87)\end{array}$ & $\begin{array}{l}2.59 * * \\
(1.24)\end{array}$ & NA & $\begin{array}{l}0.49 * * \\
(0.20)\end{array}$ & $\begin{array}{c}0.36 \\
(1.44)\end{array}$ & 4.79 \\
\hline
\end{tabular}

Note: Each cell includes the 2SLS estimate of the impact of growth of foreign-STEM on the dependent variable listed at the top of the column. The instrument used is the imputed growth of foreign- STEM workers. The specification estimated is as $\left({ }^{* *}\right)$ in the text. It always includes period effects. The standard errors are heteroskedasticity-robust and clustered at the metro-area level. $* * *, * *, *$ significant at the $1,5,10 \%$ level. 
Table 7

Foreign STEM Effect on the Wages \& Employment: Split Non-College into Two groups

Panel of 17 Canadian geographic areas 1991-1996, 1996-2001, 2001-2006

\begin{tabular}{lcccc}
\hline Specification: & $\begin{array}{c}(\mathbf{1}) \\
\text { Weekly Wage, } \\
\text { Native High } \\
\text { School } \\
\text { graduates }\end{array}$ & $\begin{array}{c}\text { Weekly Wage, } \\
\text { Native No high } \\
\text { school degree }\end{array}$ & $\begin{array}{c}\text { (3) } \\
\text { Employment, } \\
\text { Native High } \\
\text { School } \\
\text { graduates }\end{array}$ & $\begin{array}{c}\text { (4) } \\
\text { Employment, } \\
\text { Native No high } \\
\text { school degree }\end{array}$ \\
\hline $\begin{array}{l}\text { Imputed Change in Foreign- } \\
\text { STEM }\end{array}$ & 2.16 & $\begin{array}{c}4.22^{*} \\
(2.58)\end{array}$ & $\begin{array}{c}-0.49 \\
(1.41)\end{array}$ & $0.91^{* *}$ \\
\hline Observations & $(1.63)$ & 51 & 51 & 51 \\
\hline Period Effects & 51 & Yes & Yes & Yes \\
\hline $\begin{array}{l}\text { K-P Wald F-Statistic of the } \\
\text { First Stage }\end{array}$ & 13.87 & 13.87 & 13.87 & 13.87 \\
\hline
\end{tabular}

Note: Each cell includes the 2SLS estimate of the impact of growth of foreign-STEM on the dependent variable listed at the top of the column. The instrument used is the imputed growth of foreign- STEM workers. The specification estimated includes period effects. The standard errors are heteroskedasticity-robust and clustered at the metro-area level. $* * *, * *, *$ significant at the $1,5,10 \%$ level. 
Table 8

2SLS Regression of Foreign-STEM on House Rental Prices

Panel of 17 Canadian geographic areas 1991-1996, 1996-2001, 2001-2006

\begin{tabular}{lcccc}
\hline Specification: & $\begin{array}{c}(\mathbf{1}) \\
\text { Median Rent, } \\
\text { College- } \\
\text { Educated }\end{array}$ & $\begin{array}{c}\text { (2) } \\
\text { Median Rent, } \\
\text { Non College- } \\
\text { Educated }\end{array}$ & $\begin{array}{c}\text { (3) } \\
\text { As (1) } \\
\text { controlling for } \\
\text { 1981 native } \\
\text { STEM } \\
\text { dependence }\end{array}$ & $\begin{array}{c}\text { (4) } \\
\text { As (2) controlling } \\
\text { for 1981 native } \\
\text { STEM dependence }\end{array}$ \\
\hline $\begin{array}{l}\text { Imputed Change in Foreign- } \\
\text { STEM }\end{array}$ & $\begin{array}{c}4.01^{* *} \\
(2.19)\end{array}$ & $\begin{array}{c}\text { (1.3) } \\
(1.51)\end{array}$ & $\begin{array}{c}4.05^{*} \\
(2.30)\end{array}$ & $\begin{array}{c}2.36 \\
(1.50)\end{array}$ \\
\hline Observations & 51 & 51 & 51 & 51 \\
\hline Period Effects & Yes & Yes & Yes & Yes \\
\hline K-P Wald F-Statistic of the & 13.87 & 13.87 & 14.04 & 14.04 \\
First Stage & & & & \\
\hline
\end{tabular}

Note: Each cell includes the 2SLS estimate of the impact of growth of foreign-STEM on the dependent variable listed at the top of the column. The instrument used is the imputed growth of foreign- STEM workers. The standard errors are heteroskedasticity-robust and clustered at the metro-area level. $* * *, * *, *$ significant at the $1,5,10 \%$ level. 
Table 9

Compare the effects of foreign STEM: US versus Canada

17 Canadian geographic areas 1991-1996, 1996-2001, 2001-2006;

219 U.S. Metropolitan Areas 1990-2000, 2000-2005, and 2005-2010

\begin{tabular}{|c|c|c|c|c|c|c|c|}
\hline $\begin{array}{l}\text { Explanatory Variable: } \\
\text { Imputed Growth in } \\
\text { Foreign-STEM }\end{array}$ & $\begin{array}{c}\text { (1) } \\
\text { Growth Rate } \\
\text { in Weekly } \\
\text { Wage, Native } \\
\text { STEM }\end{array}$ & $\begin{array}{c}\text { (2) } \\
\text { Growth Rate } \\
\text { in Weekly } \\
\text { Wage, } \\
\text { Native } \\
\text { College- } \\
\text { Educated }\end{array}$ & $\begin{array}{c}\text { (3) } \\
\text { Growth } \\
\text { Rate in } \\
\text { Weekly } \\
\text { Wage, } \\
\text { Native Non- } \\
\text { College- } \\
\text { Educated }\end{array}$ & $\begin{array}{c}\text { (4) } \\
\text { Growth Rate } \\
\text { in } \\
\text { Employment, } \\
\text { Native STEM }\end{array}$ & $\begin{array}{c}\text { (5) } \\
\text { Growth rate } \\
\text { in } \\
\text { Employment, } \\
\text { Native } \\
\text { College- } \\
\text { Educated }\end{array}$ & $\begin{array}{c}\text { (6) } \\
\text { Growth Rate } \\
\text { in } \\
\text { Employment, } \\
\text { Native Non- } \\
\text { College- } \\
\text { Educated }\end{array}$ & $\begin{array}{l}\text { K-P Wald F- } \\
\text { Statistic of } \\
\text { the First } \\
\text { Stage }\end{array}$ \\
\hline $\begin{array}{l}\text { Basic Specification, } \\
\text { Canada Estimates }\end{array}$ & $\begin{array}{l}2.28^{*} \\
(1.30) \\
\end{array}$ & $\begin{array}{l}5.52^{* *} \\
(2.64)\end{array}$ & $\begin{array}{c}2.97 \\
(1.92)\end{array}$ & $\begin{array}{c}0.14 \\
(0.35) \\
\end{array}$ & $\begin{array}{c}0.56 \\
(0.40) \\
\end{array}$ & $\begin{array}{c}0.42 \\
(1.77)\end{array}$ & 13.87 \\
\hline $\begin{array}{l}\text { Basic Specification, US } \\
\text { estimates }\end{array}$ & $\begin{array}{l}7.81^{* *} \\
(1.93)\end{array}$ & $\begin{array}{c}4.98 * * * \\
(1.20)\end{array}$ & $\begin{array}{l}-0.46 \\
(0.96)\end{array}$ & $\begin{array}{c}0.14 \\
(0.52)\end{array}$ & $\begin{array}{c}1.80 \\
(1.52)\end{array}$ & $\begin{array}{l}-3.51 \\
(2.67)\end{array}$ & 17.20 \\
\hline
\end{tabular}

Note: The estimated elasticity values reported for Canada in Row are from table 6. Those for the United States are from Peri, Shih and Sparber (2013), table 9, row 1. The specification estimated includes period effects. The standard errors are heteroskedasticity-robust and clustered at the metro-area level. ***,**, * significant at the 1, 5, 10\% level. 


\section{Figure 1}

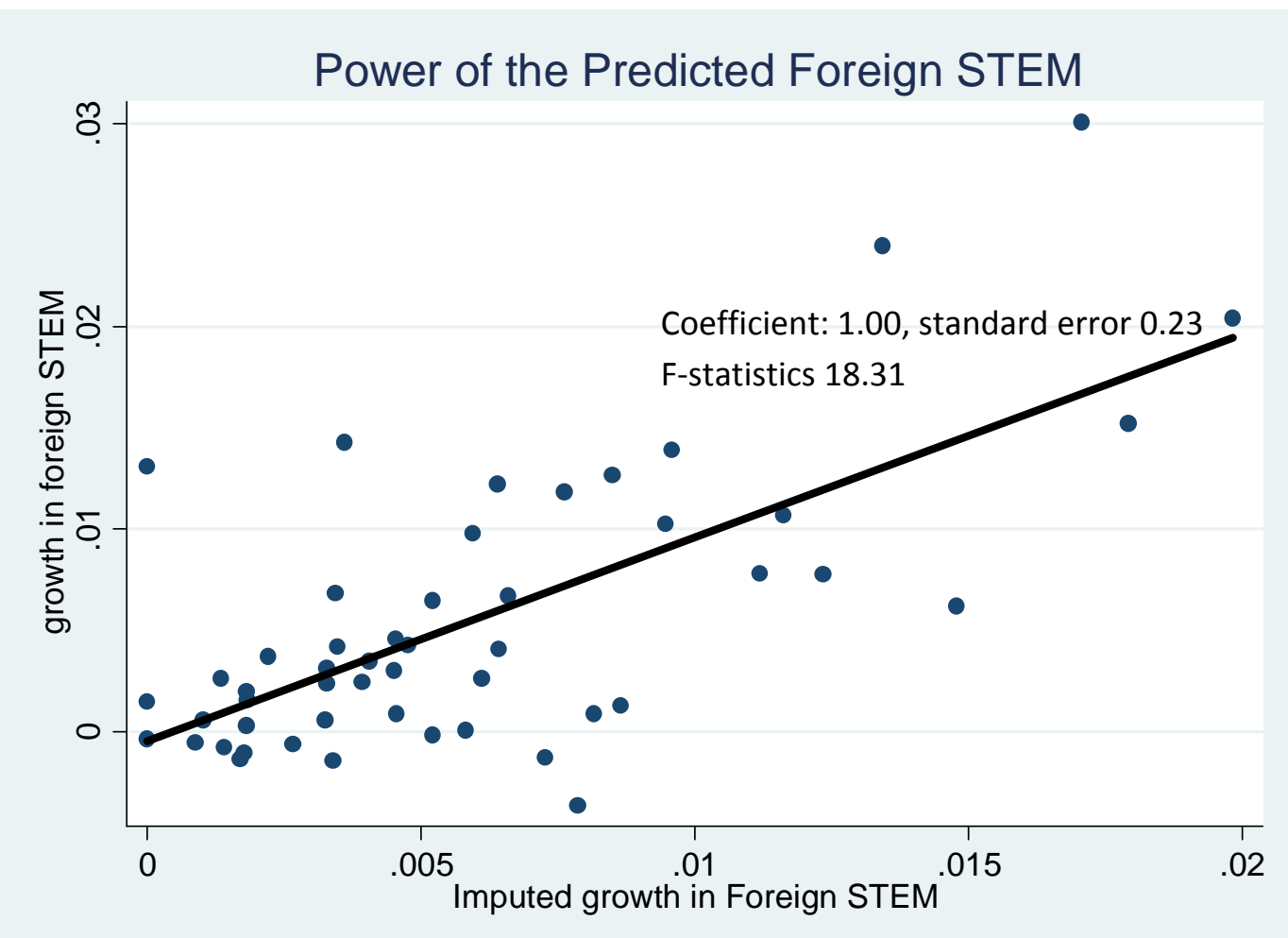

Note: Power of the predicted STEM variable in predicting actual growth of STEM immigrants in Canadian geographic areas. 